\title{
Hormone Consumption among Mak Nyahs in Kuantan Town: A Preliminary Survey
}

\author{
Draman $S^{a}$, Maliya $S^{a}$, Farhan $A^{a}$, Syazwan $S^{a}$, Nur 'Atikah $A^{a}$, KH Abd Aziz' \\ ${ }^{a}$ Department of Family Medicine, Kulliyyah of Medicine, 25200 Indera Mahkota, Kuantan, Pahang \\ ${ }^{b}$ Department of Community Medicine, Kulliyyah of Medicine, International Islamic University Malaysia, \\ 25200 Indera Mahkota, Kuantan, Pahang
}

\begin{abstract}
Introduction: Mak nyahs (male-to-female transgenders) often consume feminizing hormones to achieve and maintain the female physical appearance. They do it without professional prescription/advise, and often take excessive doses. This renders them at risk of developing complications of hormone consumption. This paper provides some quantitative data on hormone consumption among mak nyahs in Kuantan, Pahang, in Malaysia. Materials and Methods: A cross-sectional study was carried out from July to August in 2015 among 35 mak nyahs. Convenience sampling was used. Participants who gave consent answered an interview-guided questionnaire which documents socio-demographic profile, hormone usage, and morbidities as a result of hormone consumption. Data was analysed using SPSS, Version 16.0. (version 16). Results: Majority of the subjects were Malays (91.4\%) and Muslims (97.1\%), their median (IQR) age being $31( \pm 17)$ years, more than half $(57.1 \%)$ were between 20 to 40 years old. Most $(80.0 \%)$ of them are sex workers. Oral hormone was most commonly used (88.6\%), while more than half $(67.7 \%)$ of them added hormone injections. Almost all subjects purchased hormones over the counter from local pharmacies (94.2\%). However, many received information on hormone from non-professional sources. Possible adverse effects of hormones reported among subjects were hypertension, ischemic heart disease, diabetes mellitus, and venous thrombo-embolism. Conclusion: Hormone consumption was very common among the subjects in this study, and may be associated with certain medical problems. Medical personnel must pay more attention in educating the mak nyahs on adverse effects of hormones consumption. Mak nyahs should also be screened for complications every time they seek medical attention.
\end{abstract}

KEYWORDS: Transgender, transsexual, mak nyah, hormone, sex workerz

\section{INTRODUCTION}

The term transgender refers to the group of individuals who transiently or persistently identify with a gender different from their natal gender. The prevalence of male-to-female transgenders is usually higher than the prevalence of female-tomale transgenders. 1,2

In many countries, transgenders suffer from discriminations in education, employment, and healthcare because of their gender expression. They

Corresponding author:

Samsul Draman

Department of Family Medicine

Kulliyyah of Medicine

International Islamic University Malaysia

25200 Indera Mahkota

Kuantan, Pahang.

Mobile: $+6013-9827277$

Tel: $+609-5704572$ (tel)

Fax: +609-5716542 (fax)

Email: nurin@iium.edu.my also face violence, criminalization, and prosecution in many countries. ${ }^{3}$ There are more than 50,000 transgenders in Malaysia. ${ }^{4}$ In the Malay language, a male-to-female transgender is called a mak nyah. ${ }^{5}$ In Malaysia, majority (86.6\%) of mak nyahs are involved in the sex trade $^{6}$ because of social marginalization, economic instability, and difficulty in finding and maintaining proper employment. ${ }^{3,5,7}$

From adolescence, mak nyahs take female hormones orally or through injections to change their male physical appearance to a female body. ${ }^{5-10}$ Breast enlargement is of special importance to mak nyahs because it represents their new gender. ${ }^{8}$ Oestrogen is the most important hormone for physical changes, and progesterone and anti-androgen are sometimes added to potentiate the effects of oestrogen. ${ }^{8,11}$ These hormones could also give the mak nyahs a smooth complexion, reduce body and facial hair, as well as reduce penile erection. ${ }^{10,12}$

Since mak nyahs need to maintain their female physical appearance to attract more customers during sex trade, ${ }^{5}$ hence they tend to consume very high doses of these hormones to reach more rapid 
changes $^{11}$, however/sadly they are unaware of the complications of the hormones..$^{5,7,10}$ Important/ significant complications of feminizing hormones include depression, venous thrombo-embolism, myocardial infarction, stroke, and adverse liver effects. Decrease in haemoglobin and reduction in insulin sensitivity have also been reported. ${ }^{11}$

In Malaysia, currently there is no quantitative data on the hormone consumption among the mak nyah community. This paper aims to describe the sociodemography profile of mak nyahs in Kuantan, to investigate their hormone consumption, and to document any possible adverse effects resulting from taking the feminizing hormones.

\section{MATERIALS AND METHODS}

An interview-guided questionnaire was used in this cross-sectional study. The questionnaire was developed by researchers after extensive literature review. It was then face-validated by a specialist in Family Medicine and a specialist in Community Medicine from International Islamic University Malaysia. It consists of 3 parts: the first part records the socio-demographic profile of the subjects, the second part investigates their hormone, while the third part documents morbidities as a result of hormone consumption.

There is a non-governmental organization, named Persatuan Insaf Pahang, which looks after the psycho-social and spiritual welfares of mak nyahs in Kuantan, Pahang. A representative from Persatuan Insaf Pahang was contacted for the purpose of this research. The representative is a mak nyah, and is familiar with the mak nyah community in Pahang.

At the time of this study, there was no proper documentation on the population size of mak nyahs in Kuantan. However, according to the representative, it was estimated that there were about 50 mak nyahs in Kuantan, and there were 4 areas in Kuantan where mak nyahs usually congregate/convene. Thus, the survey was carried out in these 4 areas, and subjects encountered in these 4 areas during the study represent the mak nyahs of the entire town. This study span over six weeks from July to August, 2015.

Before the official commencement of the survey, a discussion was held between the representative and the researchers to ensure techniques in approaching the subjects remained professional and standardized. The survey was conducted in Bahasa Malaysia. The research protocol was approved by IIUM Research Ethical Committee (ethical approval no).

Inclusion criteria for subjects in this research include self-identified mak nyahs who lived in Kuantan, aged above 18, and could communicate in
Bahasa Malaysia. During the survey, subjects were approached face-to-face to establish rapport, were screened to meet the inclusion criteria, and were explained the purpose and procedure of this study. Despite maximum effort put in recruiting subjects from these 4 areas, out of the 39 mak nyahs who were willing to be approached, only 35 mak nyahs gave consent for participation. Participation was voluntary and anonymous. After the data collection process, all subjects were counselled by the researchers to continue seeking professional help for their morbidities.

In this study, a subject who had taken any feminizing hormone during his lifetime was considered a hormone user. The brands or generic names of these feminizing hormones were recorded during data collection, and the researchers further classified these hormones into containing "oestrogen-only", “oestrogen and progesterone", "oestrogen and anti-androgen with/without progesterone". The morbidities as a result of hormone consumption were diagnosed by qualified doctors, as reported by the subjects themselves.

Data analysis was then analyzed using SPSS, Version 16.0. (SPSS Inc. Released 2007. SPSS for Windows, Version 16.0. Chicago, SPSS Inc).

\section{RESULTS}

The socio-demographic profile of the 35 mak nyahs is shown in Table 1. Majority (91.4\%) were Malays, the rest were an Indian (2.9\%), a Chinese $(2.9 \%)$, and a non-Malaysian (2.9\%). All of them were Muslims, except the non-Malaysian. The age of these subjects ranged from 18 to 59 years, with a median (IQR) of $31( \pm 17)$ years. More than half $(57.1 \%)$ of the subjects were 20 to 40 years old, $5.7 \%$ were below 20, and $37.1 \%$ were above 40 years. Most $(88.6 \%)$ of the subjects were never married, while $11.4 \%$ were currently married.

Most (94.3\%) of the subjects received formal education (in schools, colleges, and universities). Their education levels varied from up to tertiary $(20.0 \%)$, secondary $(65.7 \%)$, and primary $(8.6 \%)$. Majority $(80.0 \%)$ of the subjects reported to be "sex worker", the rest of the subjects were "employee in private sectors" (11.4\%), "employee in government sectors" $(2.9 \%)$, and "retired/ student/unemployed" (5.7\%).

Those who have a monthly income $(80.0 \%)$ reported amounts ranged from RM500 to RM20000; with a median (IQR) of RM2750 (RM3475). About half (51.5\%) of them earned more than RM2000 a month, $15.2 \%$ of them earned less than RM1000 monthly, $24.2 \%$ earned between RM1000 to RM2000.

Out of the 35 subjects, $11.4 \%(n=4)$ reported no history of hormone use. The remaining $88.6 \%$ consumed hormone in the form of oral contraceptive 
pills (OCPs) and hormone injections. Among the 31 additional hormones in the form of injections, while subjects who used hormone, as shown in Table 2, the remaining 32.3\% took OCPs only. the $67.7 \%$ subjects who took oral hormones received

Table 1 Socio-demographic profile of the mak nyah subjects in Kuantan, Pahang. $(\mathrm{N}=35)$

\begin{tabular}{|c|c|c|}
\hline & n (\%) & $\begin{array}{l}\text { Median (IqR) } \\
\text { Mean (SD) }\end{array}$ \\
\hline Age (years) & & $\begin{array}{c}31(17) \\
35.2(11.84)\end{array}$ \\
\hline below 20 & $2(5.7)$ & \\
\hline 20 to 29 & $11(31.4)$ & \\
\hline 30 to 39 & $9(25.7)$ & \\
\hline 40 to 49 & $8(22.9)$ & \\
\hline 50 to 59 & $5(14.3)$ & \\
\hline 60 and above & $0(0.0)$ & \\
\hline \multicolumn{3}{|l|}{ Race } \\
\hline Malay & $32(91.4)$ & \\
\hline Indian & $1(2.9)$ & \\
\hline Chinese & $1(2.9)$ & \\
\hline Others & $1(2.9)$ & \\
\hline \multicolumn{3}{|l|}{ Education } \\
\hline Primary & $3(8.6)$ & \\
\hline Secondary & $23(65.7)$ & \\
\hline Tertiary & $7(20.0)$ & \\
\hline Others & $2(5.7)$ & \\
\hline \multicolumn{3}{|l|}{ Work status } \\
\hline Government Employee & $1(2.9)$ & \\
\hline Private Employee & $4(11.4)$ & \\
\hline Sex worker & $28(80.0)$ & \\
\hline Retired /Student /Unemployed & $2(5.7)$ & \\
\hline Income per month (Ringgit Malaysia) & & $\begin{array}{c}2750(3475) \\
3746.4(3826.07)\end{array}$ \\
\hline below 1000 & $2(5.7)$ & \\
\hline 1000 to 1999 & $6(17.1)$ & \\
\hline 2000 to 2999 & $6(17.1)$ & \\
\hline 3000 to 3999 & $3(8.6)$ & \\
\hline 4000 to 4999 & $3(8.6)$ & \\
\hline 5000 to 9999 & $6(17.1)$ & \\
\hline 10000 and above & $2(5.7)$ & \\
\hline \multicolumn{3}{|l|}{ Marital Status } \\
\hline Currently Married & $4(11.4)$ & \\
\hline Never Married & 31 (88.6) & \\
\hline Divorced & $0(0.0)$ & \\
\hline
\end{tabular}


Table 2 Types, content, and frequency of hormone use by mak nyah subjects in Kuantan, Pahang. $(n=31)$

\begin{tabular}{lcc}
\hline & $\mathrm{n}$ & $\begin{array}{c}\text { Percent- } \\
\text { age (\%) }\end{array}$ \\
\hline $\begin{array}{l}\text { Type of hormone } \\
\quad \text { Oral only }\end{array}$ & 10 & 32.3 \\
$\quad$ Injection only & 0 & 0.0 \\
Both & 21 & 67.7 \\
$\begin{array}{l}\text { Hormone content } \\
\text { Oestrogen only }\end{array}$ & 2 & 6.5 \\
$\begin{array}{l}\text { Oestrogen and progesterone } \\
\text { Oestrogen and anti-androgen } \\
\text { with/without progesterone }\end{array}$ & 9 & 29.0 \\
\hline
\end{tabular}

The most common type of hormone used was "oestrogen and anti-androgen with/without progesterone" (64.5\%), while others were "oestrogen only" (6.5\%), and "oestrogen and progesterone" (29.0\%). All oestrogen used among the subjects was ethinylestradiol. As demonstrated in Table 3, $90.3 \%$ of the subjects took OCPs daily, and more than half $(66.7 \%)$ of them took hormone in the form of injections at least once a week.

The hormone was obtained from a variety of sources. Most of the time, hormone was purchased "from pharmacies" (94.2\%), many obtained "from friends" (41.3\%), some purchased "from physicians" (35.5\%), while a portion of the subjects reported purchasing hormone "from black market" (22.6\%), and "others" (34.2\%).

The subjects in this study received information about the hormone they use from sources including "physicians" (58.1\%), "friends" (56.1\%), "internet" (44.5\%), and "newspapers and magazines" (35.5\%).

In this study, those who had no history of using hormone did not report to have any medical problem. Out of the 31 subjects who used hormone, 5 possible adverse effects might be associated with hormone use were sought (Table 4). The most common morbidity was hypertension (12.9\%), followed by diabetes mellitus $(9.7 \%)$.

Table 3 Frequency of hormone use among the mak nyah subjects in Kuantan.

\begin{tabular}{|c|c|c|}
\hline $\begin{array}{l}\text { Frequency of } \\
\text { use }\end{array}$ & $\begin{array}{r}\text { Oral, } n=31 \\
n(\%)\end{array}$ & $\begin{array}{rr}\text { Injection, } & n=21 \\
& n(\%) \\
\end{array}$ \\
\hline Everyday & $28(90.3)$ & $0(0.0)$ \\
\hline $\begin{array}{l}\text { Several times a } \\
\text { week }\end{array}$ & $2(6.5)$ & $6(28.6)$ \\
\hline Once a week & $1(3.2)$ & $8(38.1)$ \\
\hline Once in 2 weeks & $0(0.0)$ & $5(23.8)$ \\
\hline Once a month & $0(0.0)$ & $2(9.5)$ \\
\hline
\end{tabular}

Table 4 Possible medical problems which might be associated with hormone use among mak nyahs in Kuantan, Pahang. ( $\mathrm{N}=31)$

\begin{tabular}{|c|c|c|c|}
\hline $\begin{array}{l}\text { Medical } \\
\text { Problems }^{\dagger}\end{array}$ & n (\%) & $\begin{array}{r}\text { Age of } \\
\text { subject } \\
\text { when the } \\
\text { medical } \\
\text { problem was } \\
\text { diagnosed }\end{array}$ & $\begin{array}{r}\text { Years of } \\
\text { taking } \\
\text { hormone } \\
\text { when the } \\
\text { medical } \\
\text { problem } \\
\text { was } \\
\text { diagnosed }\end{array}$ \\
\hline & & $\begin{array}{r}\text { Median } \\
\left(\text { IqR }^{*}\right)\end{array}$ & $\begin{array}{r}\text { Median } \\
\text { (IqR) }\end{array}$ \\
\hline Hypertension & $\begin{array}{r}4 \\
(12.9)\end{array}$ & $52.0(20.0)$ & $22.5(20.0)$ \\
\hline $\begin{array}{l}\text { Diabetes } \\
\text { Mellitus }\end{array}$ & $3(9.7)$ & $46.0(-)$ & $5.0(-)$ \\
\hline $\begin{array}{l}\text { Venous } \\
\text { thrombo- } \\
\text { embolism }\end{array}$ & $1(3.2)$ & $59.0(-)$ & $25.0(-)$ \\
\hline $\begin{array}{l}\text { Myocardial In- } \\
\text { farction }\end{array}$ & $1(3.2)$ & $24.0(-)$ & $1.0(-)$ \\
\hline $\begin{array}{l}\text { End stage renal } \\
\text { disease }\end{array}$ & $1(3.2)$ & $24.0(-)$ & $1.0(-)$ \\
\hline
\end{tabular}

* IqR - inter-quartile range

${ }^{\dagger}$ A few subjects had multiple medical problems

\section{DISCUSSION AND RECOMMENDATION}

This is a preliminary survey on consumption of feminizing hormone among mak nyahs in Kuantan, Pahang. The results/findings from this study showed that hormone consumption is a common practice in this community.

Majority of the subjects in this study were from the younger population, with a median age of 31 years and the largest age group being the "20 to 29 year" group $(n=11 ; 31.4 \%)$. This result was similar to a large qualitative study in Mumbai, 2015, as well as a national study in Malaysia, 2008., ${ }^{7,13}$ Studies in Thailand in 2006 and 2011 had subjects of even younger age (mean=24.1 years to 25.4 years) ${ }^{9,14}$ Researchers in this study are concerned that taking excessive hormone at a younger age could lead to early development of morbidities, followed by poor quality of life in terms of health as the subjects get older. ${ }^{11,15}$

It was interesting to find that $11.4 \%$ of the subjects in this study were officially married. This could be because they still desired to have a normal family although they were mak nyahs, or they could be fulfilling the family's expectations and following the cultural norms. ${ }^{12} \mathrm{~A}$ qualitative study in the future to understand the psycho-social and psycho-sexual phenomena of these mak nyahs would be helpful.

More than half of the subjects received secondary education. This observation corresponds with the percentage of secondary school enrolment for male students in Malaysia $(67.0 \%){ }^{16}$ A few subjects completed up to tertiary education, while some only 
received primary education, similar to previous studies in Malaysia on mak nyahs. ${ }^{17,} 18$

In this study, $80.0 \%$ of the subjects were found to be involved in the sex trade. This observation was higher than the finding from a similar study in Kuantan just a year ago, where there were just $60.6 \%$ subjects who reported to be sex workers. ${ }^{17}$ This was an alarming increase, because many mak nyahs do not practice safe sex, and thus render themselves as well as the general public (is the general public at high risk or those soliciting the mak nyahs services at high risk?) high risk of being infected with HIV and other sexually transmitted diseases. $^{7,19-22}$

In addition, majority of the subjects in this study were Malays and Muslims. This finding is consistent with a few other studies done in Malaysia. 7, 10, 12, 18, ${ }^{23}$ The high number of Muslims mak nyahs involved in the sex trade ought to be a concern for Muslim researchers and religious authorities. In Islam, sex trade, or prostitution, is prohibited. ${ }^{24-26}$ One of the reasons these mak nyahs are involved in the sex trade could be due to discriminations they face in

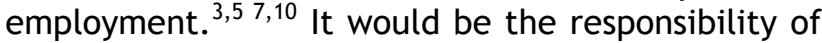
the entire Muslim community to help the mak nyahs in a more humane approach. Researchers in this study would strongly urge the Muslim community to provide employment opportunities and relevant trainings to strengthen the mak nyah community, with the hope that they could eventually attain better quality of life. In addition, although the average income of the subjects in this study (mean $=\mathrm{RM} 3746$, median $=\mathrm{RM} 2750$ ) was higher than that of the previous year $($ mean $=\mathrm{RM} 1528),{ }^{17}$ the income was lower than the average household income in Pahang (RM4343) in 2014. ${ }^{27}$ Majority (88.6\%) of the subjects in this study had consumed feminizing hormones in his lifetime. This finding is consistent with observations/reports from the United States $(82 \%)$, and Thailand (88.6\% and 93.8\%). ${ }^{9}, 14,28$

Of the subjects who took feminizing hormones, all of them consumed oral hormones in the form of oral contraceptive pills. This could be because oral contraceptive pills are easily available over-thecounter medications in Malaysia. ${ }^{7}$ Worryingly, $67.7 \%$ of those who consumed oral hormones also took hormones in injections form. Unsupervised hormone consumption often leads to excessive intake of these hormones to reach rapid desired feminizing result. ${ }^{11}$ High dose of oestrogen often leads to adverse complications such as thrombo-embolytic disease, pulmonary embolism, myocardial infarction, stroke, and adverse liver effects $^{11}$, but mak nyahs often prefer hormonal injections because these provide a higher level of circulating oestrogen and therefore accelerated the feminization process. ${ }^{15}$ More than half $(64.5 \%)$ of them took oestrogen and anti-androgen with/ without progesterone. The concurrent usage of oestrogen with anti-androgen or progesterone is believed to have synergistic effects to oestrogen and give more promising results. ${ }^{8}$

The subjects would usually purchase the hormones either from pharmacies or through friends as per reported by previous studies. ${ }^{5} 7$ However, it was alarming that some were bought in the black markets, because the content of these hormones could cause harm to the subjects.

Only about $60.0 \%$ of the times (is it $60 \%$ of the time or $60 \%$ of the subject?) that mak nyah subjects received information on feminizing hormones from physicians. This indicates that medical professionals need to be more proactive in educating the mak nyah community about hormones, especially the contraindications and complications of these hormones. From this study, friends were also an important source of information. The mak nyah community is known to have a very important role in educating and helping its own members. ${ }^{5}$ Thus, for healthcare professionals, when educating mak nyah patients, the patients should be encouraged to spread correct information to their community.

It was interesting to note that the findings in this study showed those who had no history of using feminizing hormone $(n=4)$ did not report any medical problem. Hypertension was the most common problem among subjects who took these hormones. Diabetes mellitus and venous thromboembolism were found in this study too; their occurrences were similar to the prevalence of a study in Belgium. ${ }^{29}$ Diabetes mellitus could be because there is a reduction in insulin sensitivity among mak nyahs that have been taking hormones. $^{15,30}$

Mak nyahs in this study were using ethinylestradiol. In another study where the subjects also used ethinylestradiol ${ }^{15}$, the prevalence of venous thrombo -embolism was higher (6-8\%) than the findings of this present study., Ethinylestradiol has been identified as a major factor in the occurrence of venous thrombo-embolism due to its thrombogenic properties. $^{31}$

By examining the hormone consumption behaviours of mak nyah subjects in this study, the researchers are in the opinion that local physicians should educate their mak nyah patients on the complications and contraindications of taking feminizing hormones, and to advise them to reduce their hormone intake. Medical personnel should also perform thorough physical examinations and investigations to screen for complications of hormones consumption. Health education programs designed for the mak nyah community should not be limited to just HIV infection prevention. Complications of feminizing hormone usage poses a serious health risk on to the mak nyah community, and this issue needs to be addressed too. 


\section{Limitation}

This is the first study in Malaysia with regards to feminizing hormone consumption in the mak nyah community, thus many limitations were encountered during the research process. Firstly, the daily dose intake of hormones for the subjects in this study was not documented. Secondly, the history of medical problems was derived from subjects' own perspective, therefore it might not be accurate. Other co-morbidities and risk factors which might contribute to the existing medical problems are not adequately addressed (e.g. risk factors for ischemic heart disease, family history, etc.) It is hoped that future studies would be able to produce more robust conclusion.

\section{Conclusion}

Feminizing hormone consumption is very common among the mak nyah subjects in this Kuantan study. Medical problems/complications which might be associated with these hormone consumption were reported viz hypertension, diabetes mellitus, venous thrombo-embolism, myocardianl infarction, and end stage renal disease. Local medical personnel should be aware of the hormone consumption behaviours/ practice of mak nyahs. Health education on complications and contraindications of feminizing hormones should be made routine for mak nyah patients. Thorough clinical examinations and investigations should be performed on these patients to exclude or diagnose the complications at earlier stages, so the patients would be treated accordingly to prevent morbidities and mortalities.

Majority of the subjects in this study are sex workers, and Muslims too. Education on HIV infection prevention and treatment should be provided to this community as well. Most importantly, policy makers and religious authorities should put more effort in providing job opportunities to mak nyahs. Mak nyahs deserve to be free from discriminations, including being given the opportunity to have decent jobs.

\section{Conflict of interest}

The researchers in this study declare that there is no conflict of interest.

\section{ACKNOWLEDGEMENTS}

Immense gratitude to International Islamic University Malaysia for providing the resources and funds for this study, and to IIUM Ethics Committee for approving the research protocol of this study

\section{REFERENCES}

1. DSM-V. American Psychiatric Association: Diagnostic and Statistical Manual of Mental
Disorders, Fifth Edition. Arlington, VA, American Psychiatric Association.2013.

2. Zucker KJ, Lawrence AA. Epidemiology of gender identity disorder: Recommendations for the standards of care of The World Professional Association for Transgender Health. International Journal of Transgenderism. 2009;11(1):8-18.

3. UNAIDS. The Gap Report. UNAIDS 2014.

4. $\quad \mathrm{Ng}$ E. Malay transsexual loses court bid to change gender Kuala Lumpur, Malaysia: Yahoo! News; 2011 [cited 2016 27th August, 2016]. Available from: https://www.yahoo.com/ news/malay-transsexual-loses-court-bid-change -gender-053645639.html.

5. Gibson BA, Brown S-E, Rutledge R, et al. Gender identity, healthcare access, and risk reduction among Malaysia's mak nyah community. Global public health. 2016:1-16.

6. KKM. National Strategic plan: Ending AIDS 20162030. Ministry of Health Malaysia, Putrajaya: 2015.

7. Teh YK. HIV-related needs for safety among male-to-female transsexuals (mak nyah) in Malaysia. SAHARA: Journal of Social Aspects of HIV/AIDS Research Alliance. 2008;5(4):178-85.

8. Maycock LB, Kennedy HP. Breast care in the transgender individual. Journal of Midwifery \& Women's Health. 2014;59(1):74-81.

9. Guadamuz TE, Wimonsate W, Varangrat A, et al. HIV prevalence, risk behavior, hormone use and surgical history among transgender persons in Thailand. AIDS and Behavior. 2011;15(3):6508.

10. Teh YK. Understanding the problems of mak nyahs (male transsexuals) in Malaysia. South East Asia Research. 1998:165-80.

11. Moore E, Wisniewski A, Dobs A. Endocrine treatment of transsexual people: a review of treatment regimens, outcomes, and adverse effects. The Journal of Clinical Endocrinology \& Metabolism. 2003;88(8):3467-73.

12. Teh YK. Mak nyahs (male transsexuals) in Malaysia: The influence of culture and religion on their identity. International Journal of Transgenderism. 2001;5(3):97-03.

13. Chettiar A. Problems Faced by Hijras (Male to Female Transgenders) in Mumbai with Reference to Their Health and Harassment by the Police. International Journal of Social Science and Humanity. 2015;5(9):752.

14. Winter $\mathrm{S}$. Thai transgenders in focus: Demographics, transitions and identities. International Journal of Transgenderism. 2006;9(1):15-27.

15. Gooren LJ, Giltay EJ, Bunck MC. Long-term treatment of transsexuals with cross-sex hormones: extensive personal experience. The Journal of Clinical Endocrinology \& Metabolism. 2008;93(1):19-25.

16. UNICEF. The State of the World's Children Report 2015 Statistical Tables. UNICEF; 2015. 
17. Da S, MRb R, MAa MA, et al. Knowledge and Attitude towards HIV/AIDS among transsexuals in Kuantan, Pahang. International Medical Journal Malaysia. 2016;15(1).

18. Wei CL, Baharuddin A, Abdullah R, Abdullah Z, Ern KPC. Transgenderism in malaysia. Journal of Dharma. 2012.

19. Bockting W, Robinson B, Rosser B. Transgender HIV prevention: A qualitative needs assessment. AIDS care. 1998;10(4):50525.

20. Herbst JH, Jacobs ED, Finlayson TJ, et al. Estimating HIV prevalence and risk behaviors of transgender persons in the United States: a systematic review. AIDS and Behavior. 2008;12(1):1-17.

21. Wilson EC, Garofalo R, Harris RD, et al. Transgender female youth and sex work: HIV risk and a comparison of life factors related to engagement in sex work. AIDS and Behavior. 2009;13(5):902-13.

22. Wilson EC, Garofalo R, Harris DR, Belzer M. Sexual risk taking among transgender male-to -female youths with different partner types. American journal of public health. 2010;100 (8):1500-5.

23. Teh YK. The Mak Nyahs: male to female transsexuals in Malaysia. Singapore: Eastern Universities Press; 2002.

24. Sahih Al-Bukhari Hadith (Hadith 7.259). Narrated by Abu Juhaifa.

25. Sahih Muslim Hadith (1415). Narrated by Jabir ibn Abdullah.

26. The Holy Quran. Chapter 24, verse 33.

27. Table 2: Mean Monthly Gross Household Income by Ethnic Group, Strata and State, Malaysia, 1970-2014. Economic Planning Unit, Prime Minister's Department, Putrajaya.

28. Sanchez NF, Sanchez JP, Danoff A. Health care utilization, barriers to care, and hormone usage among male-to-female transgender persons in New York City. American Journal of Public Health. 2009;99 (4):713-9.

29. Wierckx K, Elaut E, Declercq E, et al. Prevalence of cardiovascular disease and cancer during cross-sex hormone therapy in a large cohort of trans persons: a case-control study. European Journal of Endocrinology. 2013;169(4):471-8.

30. Elbers JM, Giltay EJ, Teerlink T, et al. Effects of sex steroids on components of the insulin resistance syndrome in transsexual subjects. Clinical endocrinology. 2003;58(5):562-71.

31. Asscheman H, Gooren L, Eklund P. Mortality and morbidity in transsexual patients with cross-gender hormone treatment. Metabolism. 1989;38(9):869-73. 
